\title{
Dye Tracing Within the St. Lawrence Confining Unit in Southeastern Minnesota
}

\author{
Jeffrey A. Green ${ }^{1}$, Andrew J. Luhmann ${ }^{2}$, Andrew J. Peters ${ }^{1}$, Anthony C. Runkel ${ }^{3}$ \\ E. Calvin Alexander, Jr. ${ }^{2}$, and Scott C. Alexander ${ }^{2}$ \\ ${ }^{1}$ Minnesota Department of Natural Resources, Division of Waters, 2300 Silver Creek Road NE, Rochester, \\ MN 55906; PH (507) 285-7430; FAX (507) 285-7144; emails: jeff.green@dnr.state.mn.us \& \\ andrew.peters@dnr.state.mn.us \\ ${ }^{2}$ Geology \& Geophysics Department, University of Minnesota, 310 Pillsbury Drive. SE., Minneapolis, MN \\ 55455; PH (612) 624-3517; FAX (612) 625-3819; emails: luhm0031@umn.edu, alexa001@umn.edu \& \\ alexa017@umn.edu \\ ${ }^{3}$ Minnesota Geological Survey, 2462 University Ave W., St. Paul, MN 55114-1057 \\ PH (612) 627-4780; FAX (612) 627-4778 email: runke001@umn.edu
}

ABSTRACT: Southeastern Minnesota's karst lands support numerous trout streams. These trout streams are formed by springs discharging from Paleozoic bedrock. Dye tracing has been the tool of choice for mapping the springsheds (karst groundwater basins) that feed these springs. Previous work was focused on the Galena limestone karst. In order to accelerate springshed mapping, a two-year study was funded by the Minnesota Environment and Natural Resources Trust Fund as recommended by the LegislativeCitizen Commission on Minnesota Resources (LCCMR). Across southeastern Minnesota, numerous springs discharge from the Cambrian St. Lawrence formation. The St. Lawrence is considered to be a confining unit under the Minnesota well code. A dye trace was initiated when a stream sink was discovered in the upper St. Lawrence Formation. The sampling points included springs, stream crossings, and a municipal well that may be at risk for surface contamination. Dye was recovered at one spring in less than two weeks and at two other springs in less than three weeks. This translates into travel times of 200300 meters/day. The springs all discharge from the lower St. Lawrence Formation. The St. Lawrence contains beds of dolostone; the dye trace demonstrates that there is a karst conduit flow component in this formation. This is evidence that these springs are significantly more susceptible to degradation than previously thought.

\section{INTRODUCTION}

Trout streams depend on a steady supply of clean, cold water. Southeastern Minnesota's karst lands contain 173 designated trout streams each of which is sourced from springs. Those springs are under increasing pressure from changing land use. Additional large groundwater withdrawals for energy production and other development loom in the future. Delineation of the recharge areas or springsheds of springs is a crucial first step in their protection (Paylor, 2001; Mull et al, 1998). 
The primary tool for delineating springsheds has been dye tracing. Paleozoic bedrock aquifer systems serve as the water supply source for the trout stream springs. Virtually all of the trout stream springshed delineation efforts have been conducted in the Ordovician Galena limestone (Alexander et al.,1995; Green et al., 2005) . To date springsheds have been delineated for only 12 trout streams.

In southeastern Minnesota, numerous springs discharge from the Cambrian St. Lawrence Formation (Figure 1). The St. Lawrence is interbedded fine-grained sandstone, siltstone, dolostone and shale (Mossler, 2008). Groundwater chemistry and discharge measurements on selected St. Lawrence springs have demonstrated that they receive recent recharge. The St. Lawrence formation is considered to be a confining unit under the Minnesota Well Code but in shallow conditions the St. Lawrence functions as an aquifer and exhibits secondary porosity similar to that of fractured carbonate aquifers (Runkel et al., 2006). The hydrology of these springs has been studied only to a limited extent despite their importance for trout stream water supply.
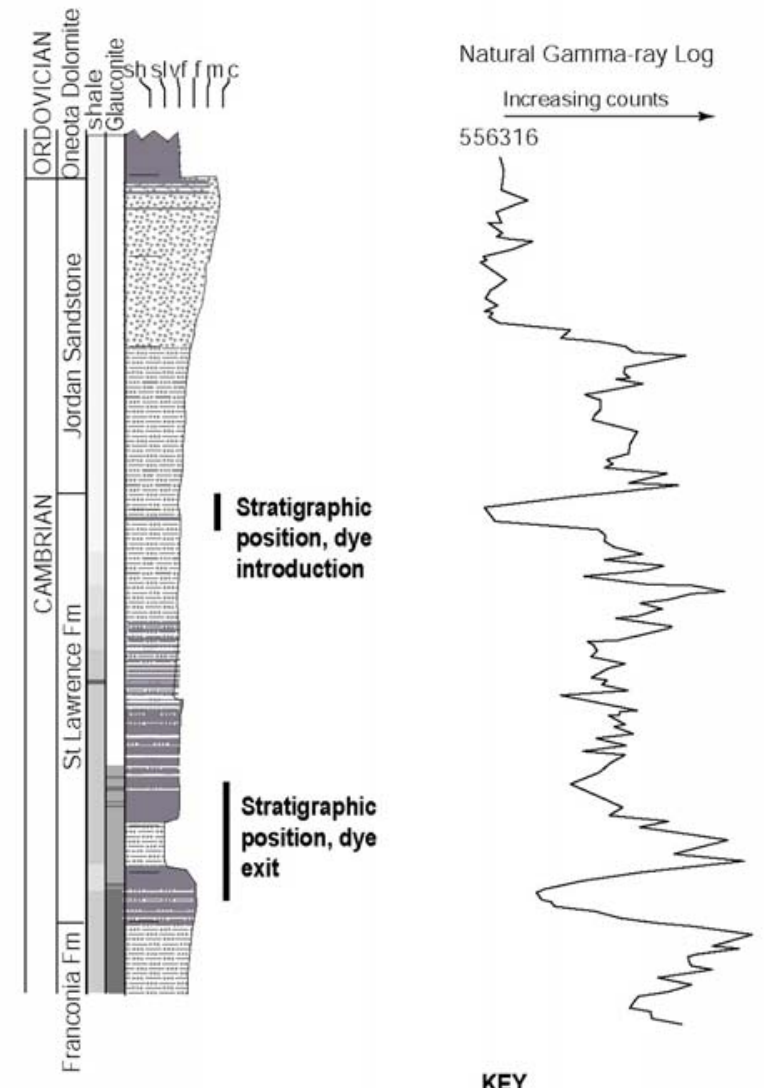

KEY

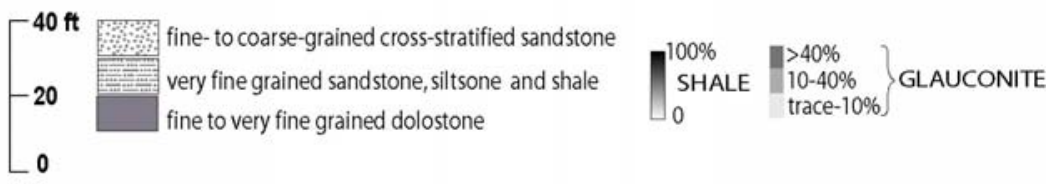

FIG. 1. Stratigraphic Column for Southeastern Minnesota. 
In September of 2007, local government staff in the City of Rushford, Minnesota located a stream sink in Ahrensfeld Creek north of the city. Subsequent field investigation by the Minnesota Department of Natural Resources and the Minnesota Geological Survey determined that the stream sink is in the upper St. Lawrence Formation. City staff members were concerned that the sinking point was in hydraulic connection to the underlying Cambrian Tunnel City Group and Wonewoc Sandstone (Mossler, 2008) which serves as the city's primary water source. In order to investigate the hydraulic attributes of St. Lawrence springs and address the staff's concern, a dye trace was initiated in the fall of 2007.

\section{METHODS}

The Minnesota Karst Features Database (KFDB) (Gao et al., 2005) contained locations of several springs in the area of interest. Several more were located through a karst field hydrogeologic survey. Passive charcoal detectors were placed at these springs, selected stream crossings, and a City of Rushford municipal well (Figure 2). Background sampling was initiated on 25 October 2007 with charcoal detectors changed weekly.

On 1 November 2007, $3.6 \mathrm{Kg}$ of 35 wt \% solution of Uranine C (Lot \#051807C-4 Chromatint, Color Index \# 45350, Chem. Abs. \# 518-47-8) were poured into the disappearing point of Ahrensfeld Creek. The flow in the stream was estimated at 500 $\mathrm{l} / \mathrm{min}$. which was all disappearing underground through the stream bed. The dye was poured into a riffle at the head of the sinking pool to facilitate mixing.

The charcoal detectors were changed weekly beginning on 8 November 2007. All charcoal detectors were returned to the University of Minnesota Geology \& Geophysics Department Hydrochemistry Laboratory for analysis. There, the charcoal detectors were opened; the charcoal was removed; and using an eluent solution of $70 \%$ isopropyl alcohol, $30 \%$ deionized water, and $10 \mathrm{~g} / \mathrm{L} \mathrm{NaOH}$; the fluorescent materials were then extracted for analysis. This elutant was then run through the Shimadzu RF5000U scanning spectrofluorophotometer to detect and record the spectra; the water samples were analyzed in the same fashion. Spectral components, including the background spectral components, were quantified using PeakFit software (Alexander, 2005).

\section{RESULTS}

Dye was detected at a stream crossing sampling site 1-2 weeks after introduction. Subsequent air photo and field investigations determined that the dye was discharging from Ehlenfeldt Spring, which was not in the KFDB. The straight line distance from the stream sink to Ehlenfeldt Spring is approximately 2200 meters. Dye was detected in the 2-3 week samples at Wolfram Spring and Borson Spring which are 3500 meters and 4000 meters from the stream sink. This translates into time of travel of 150-300 meters/day which indicates karst conduit flow. All of these springs discharge from the lower part of the St. Lawrence formation. Spectra for selected samples from Borson Spring are presented in Figure 3. The Uranine C peak is at $514-515 \mathrm{~nm}$. Dye has continued to discharge from the springs through March 2008, and it has not been detected at any other springs in that area or in the City of Rushford municipal well. The stream sink to spring 
connections discovered are shown in Figure 4 and are depicted based on standard methods (Ray, 2001)

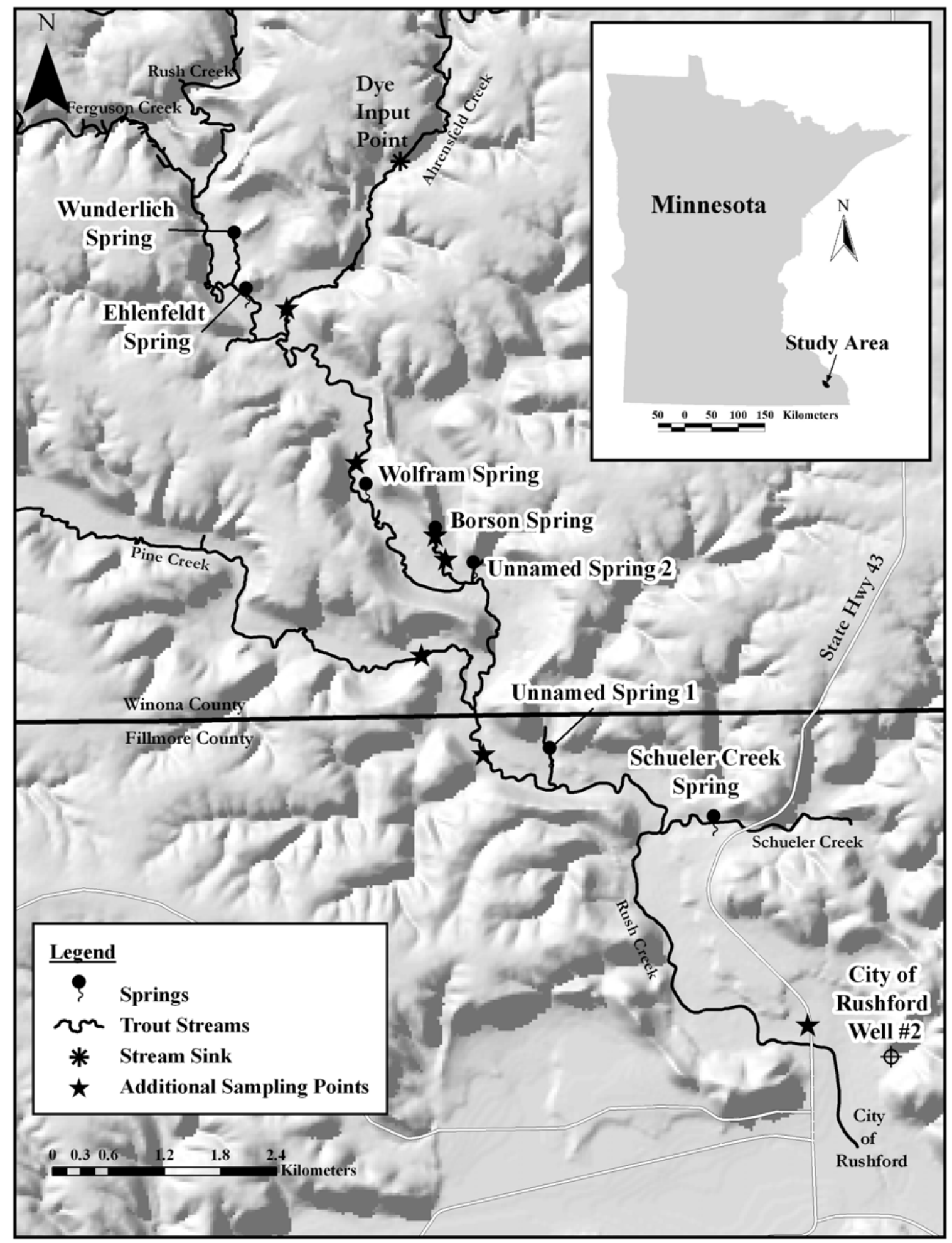

FIG. 2. Site Map of the Ahrensfeld Trace. 
A.

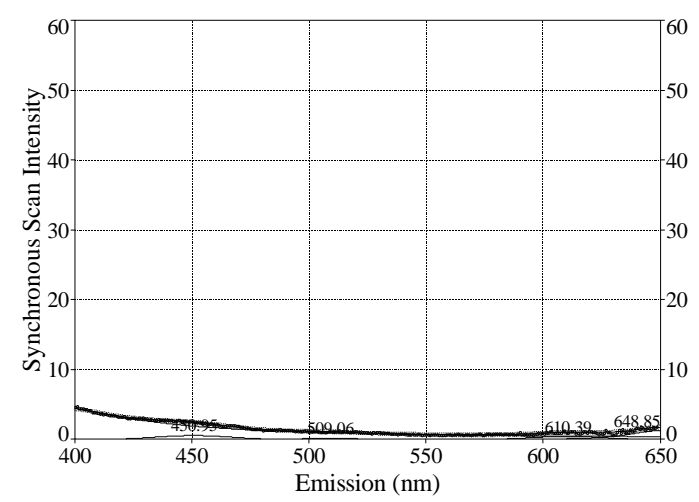

C.

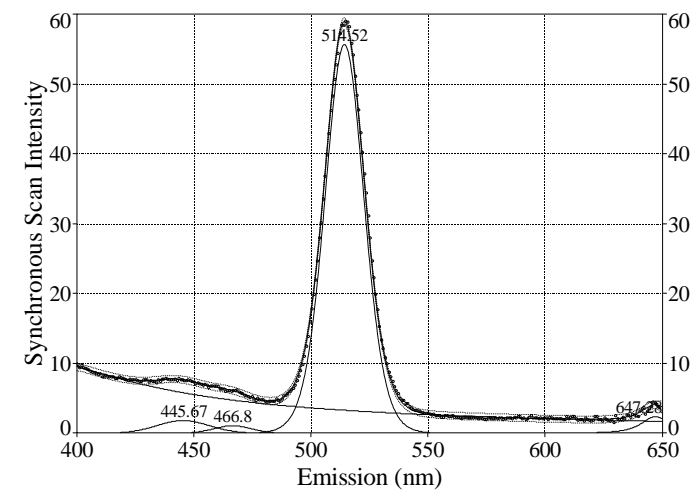

B.

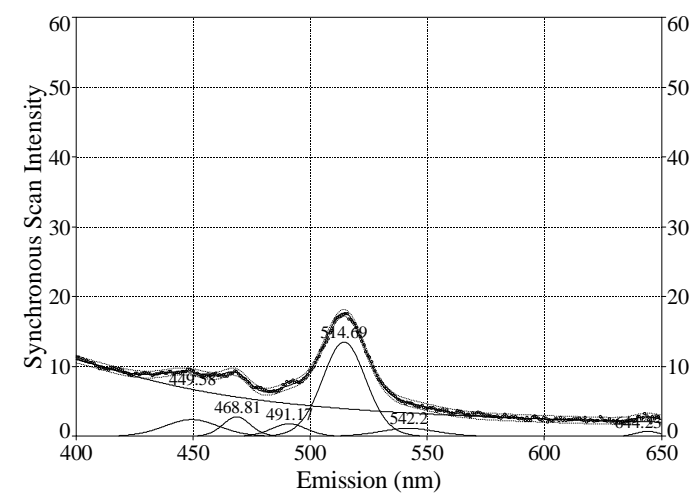

D.

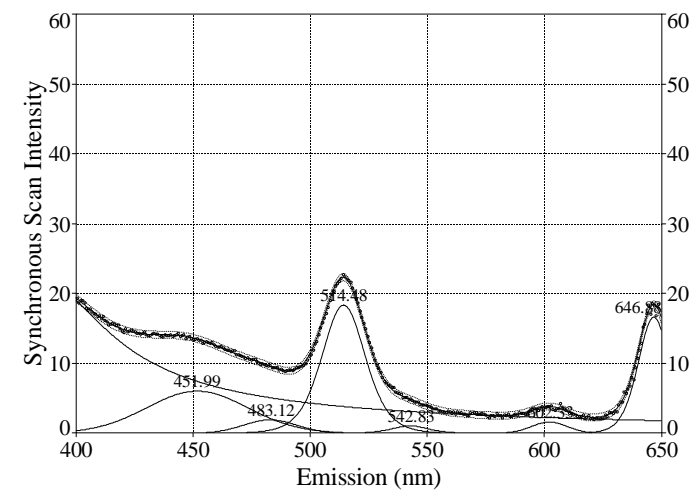

FIG. 3. Scans from Borson Spring bugs. In and out dates are: A. October 25November 1, 2007; B. November 15-23, 2007; C. November 23-29, 2007; D. April 22May 7, 2008.

\section{DISCUSSION}

To our knowledge this is the first dye trace to be run within the St. Lawrence Formation. This dye trace demonstrates a high velocity horizontal flow rate. Since the dye entered the top of the formation and exited at a point approximately $25 \mathrm{~m}$ stratigraphically lower, it also demonstrates enhanced vertical hydraulic conductivity. Prior to this dye trace, it was generally believed that St. Lawrence springs served as discharge points for the overlying Prairie du Chien carbonate aquifer and the Jordan sandstone aquifer. Since these springs typically are at the base of a forested hill slope, it is believed that there is a recent recharge component from those slopes. There was no indication that there was a karst conduit flow component to their hydrology. The springs are typically large (flows greater than $600 \mathrm{l} / \mathrm{min}$.) and serve as critical sources for trout streams. The discovery of the karst conduit flow component indicates that these springs are even more vulnerable to degradation than previously believed. One of the aspects of the springshed mapping project includes the development of Best Management Practices (BMPs) for spring and springshed protection (Currens, 2001). Prior to this dye trace, it was assumed that protecting the forested hillslopes above them was the key to water 
quality protection in St. Lawrence springs. Direct connections to surface water inputs will require the addition of watershed management components to the BMPs.

This dye trace also has improved our understanding of the hydrology of the landscape in southeastern Minnesota. The area is a dissected Paleozoic bedrock plateau that was missed by the last continental glaciation. The St. Lawrence springs often are found at the base of the nose of a bedrock ridge (Figure 4). A system of solution-enlarged conduits in the St. Lawrence that converge at these noses could explain this pattern.

The development of a karst conduit network would provide for the rapid flow rates seen in this dye trace and account for the dye resurgence at three separate springs several kilometers apart.

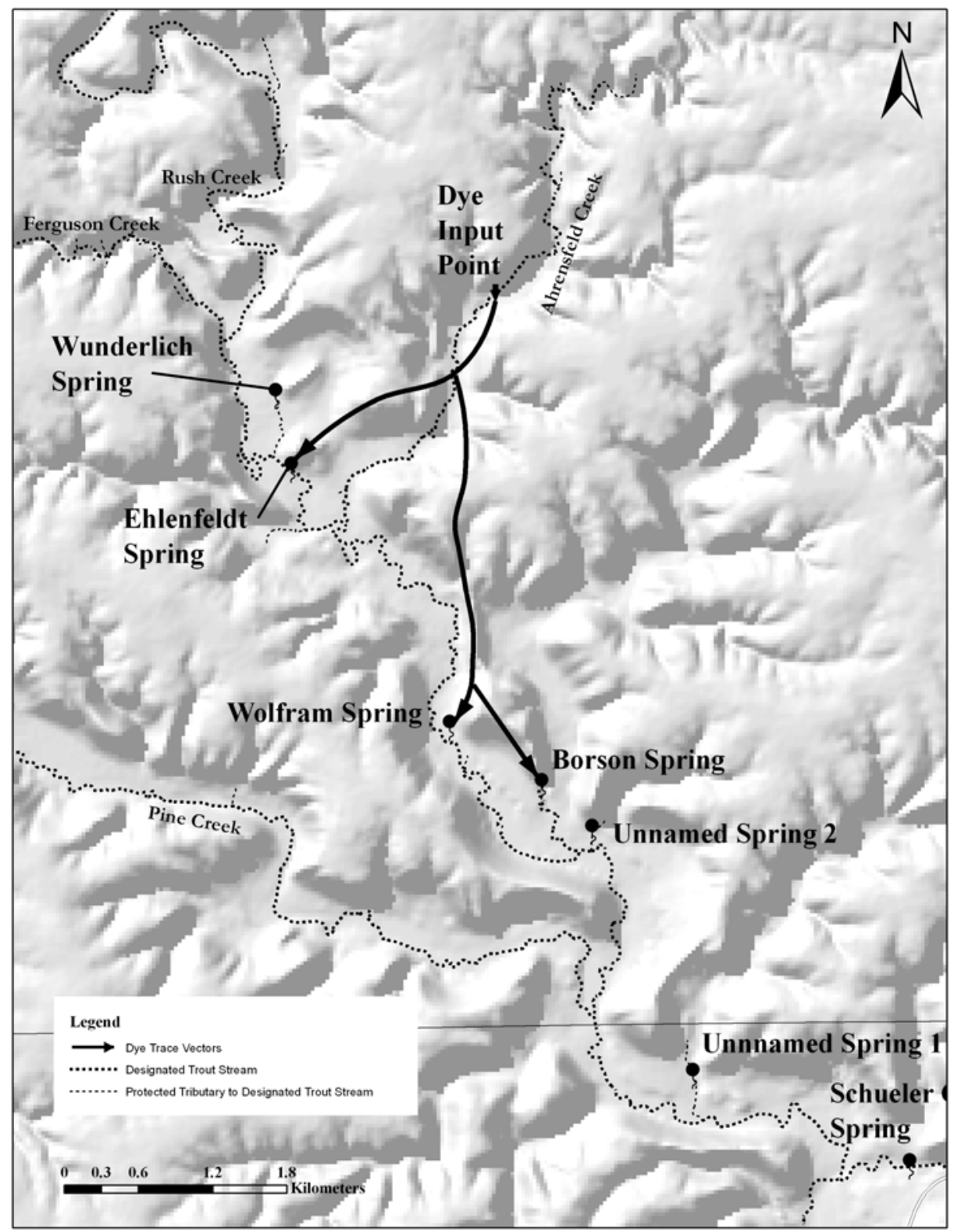

FIG. 4. Inferred Flow Routes and Spring Landscape Position. 


\section{SUMMARY}

In response to a need for more detailed investigation into the hydrology of St. Lawrence Formation springs, a dye trace was initiated from a sinking stream in the upper St. Lawrence formation. The dye traveled to three down gradient lower St. Lawrence springs at rates of 150-300 meters/day. To our knowledge, this is the first time a dye trace has been run in the St. Lawrence and documents Runkel et al.'s (2006) conclusions that the St. Lawrence Formation is not everywhere a confining unit under shallow bedrock conditions.

\section{ACKNOWLEDGEMENTS}

Funding for this project was provided by Minnesota Environment and Natural Resources Trust Fund as recommended by the Legislative-Citizen Commission on Minnesota Resources (LCCMR) and the Minnesota Department of Natural ResourcesDivision of Waters. This dye trace would not have been possible without the cooperation of local landowners and the City of Rushford's staff.

\section{REFERENCES}

Alexander, E.C. Jr., Green, J.A.., Alexander, S.C. and Spong, R.C. (1995) "Springsheds.” Plate 9 in Geological Atlas of Fillmore County, Minnesota, County Atlas Series, Atlas C-8, Part B, Minnesota Dept. of Natural Resources, St. Paul, MN.

Alexander, S.C. (2005). "Spectral deconvolution and quantification of natural organic material and fluorescent tracer dyes.” in: (Beck, B.F. ed.) Proceedings of the Tenth Multidisciplinary Conference on Sinkholes and the Engineering and Environmental Impacts of Karst, San Antonio, Texas, 24-28 September 2005. ASCE Geotechnical Special Publication 144, Amer. Soc. Civil Engr., Reston, VA, pp. 441-448.

Currens, J.C. (2001) "Changes in ground-water quality in a conduit-flow-dominated aquifer following BMP implementation.” in: (Beck, B.F. and Herring, J.G., eds.) Proceedings of the Eighth Multidisciplinary Conference on Sinkholes and the Engineering and Environmental Impacts of Karst, Louisville, Kentucky, 1-4 April 2001. A.A. Balkema, Lisse, pp. 209-216.

Gao, Y., Alexander, E.C. Jr., and Tipping R.G. (2005). "Karst database development: design and data assembly of karst features in Minnesota." Environmental Geology, (v. 47, n. 8, May 2005), pp. 1072-1082.

Green, J.A., Alexander, S.C., and Alexander, E.C. Jr. (2005). "Springshed mapping in support of watershed management." in:( Beck, B.F. ed.) Proceedings of the Tenth Multidisciplinary Conference on Sinkholes and the Engineering and Environmental Impacts of Karst, San Antonio, Texas, 24-28 September 2005. ASCE Geotechnical Special Publication 144, Amer. Soc. Civil Engr., Reston, VA, pp. 403-409.

Mossler, John H., (2008). “Paleozoic stratigraphic nomenclature for Minnesota.” Report of Investigations 65, Minn.Geological Survey, St. Paul, MN, pp. 83, 1 pl.

Mull, D.S., Lieberman, T.D., Smoot, J.L. and Woosley, L.H. (1988). “Application of dye tracing techniques for determining solute-transport characteristics of groundwater in karst terranes.” U.S. EPA 904/6-88-001. 
Paylor, R.L., and Currens, J.C. (2001). "Mapping karst ground-water basins in the inner bluegrass as a nonpoint-source management tool” (2001) in: (Beck, B.F. and Herring, J.G., eds.) Proceedings of the Eighth Multidisciplinary Conference on Sinkholes and the Engineering and Environmental Impacts of Karst, Louisville, Kentucky, 1-4 April 2001. A.A. Balkema, Lisse, pp. 209-216.

Ray, J.A. (2001). "Spatial interpretation of karst drainage basins.” in: (Beck, B.F. and Herring, J.G., eds.) Proceedings of the Eighth Multidisciplinary Conference on Sinkholes and the Engineering and Environmental Impacts of Karst, Louisville, Kentucky, 1-4 April 2001. A.A. Balkema, Lisse, pp. 209-216.

Runkel, A.C., Mossler, J.H, Tipping, R.G, and Bauer, E. J. (2006). “A hydrogeologic and mapping investigation of the St. Lawrence formation in the twin cities metropolitan area.” Open File Report 06-03, Minn. Geol. Survey, St. Paul, MN, pp. 53. 